\title{
GYÁRTÁSI TERMÉK NYOMKÖVETÉSE RFID TECHNOLÓGIÁVAL: ESETTANULMÁNY EGY HAJÓGYÁRI KÖRNYEZETBEN
}

\section{TRACKING MANUFACTURING RESOURCES WITH RFID TECHNOLOGY: A CASE STUDY FOR APPLICATIONS IN SHIPYARDS}

\author{
Weis Átila Astor ${ }^{1}$, Marcos Pedro de Botelho ${ }^{2}$, Nagy István ${ }^{3}$ \\ ${ }^{I}$ Federal University of Rio Grande - FURG - Center of Computer Science - C3. Av. \\ Itália km 8, Bairro Carreiros Rio Grande - RS, Brazil. Cellphone: +36-70-510- \\ 8213,atilaweis@furg.br \\ ${ }^{2}$ Federal University of Rio Grande - FURG - Center of Computer Science - C3. Av. \\ Itália km 8, Bairro Carreiros Rio Grande - RS, Brazil. Cellphone: +55-53- \\ 32336878,pbmarcos@furg.br \\ ${ }^{3}$ Óbudai Egyetem, Bánki Donát Gépész és Biztonságtechnikai Mérnöki Kar, Mechat- \\ ronikai és Autótechnikai Intézet, 1081 Budapest, Népszínház u. 8, \\ nagy.istvan@bgk.uni-obuda.hu
}

\begin{abstract}
The Brazilian naval industry is facing an expressive grown since the discovery of huge amounts of petroleum in deep ocean waters. This triggered many investments in this area to renew the naval fleet. Complex manufacturing systems as a shipyard requires a variety of different inputs. Otherwise, the automation in these areas, in Brazil, are inexpressive. One of the most expressive problem identified in the shipyard was the warehouse management. With the advancement of technology and lowering costs, Radio Frequency Identification systems (RFID) have become more viable for industrial applications like: supply chain management, inventory management and tracking products, for example. Therefore, in this paper we present a case study for tracking manufacturing resources in shipyards with RFID technology.
\end{abstract}

Key words: RFID, tracking position, naval industry.

\section{Összefoglalás}

A brazil hajóipar és tengerészet komoly növekedésnek indult a mélytengeri óceánokban fellelt kőolajnak köszönhetően. Ez több beruházást indított el ezen a környéken, többek között a tengerhajózási flották felújítását. A hajógyárakban komplex gyártási rendszerek szorultak felújításra. Sajnos Brazíliában ezeknek a rendszereknek az automatizálása lassan halad. Az egyik legnagyobb problémák közé tartozott a hajógyárak raktárainak menedzsmentje. Ezt a termék-szervezési, nyomkövetési problémát próbálják megkönnyíteni az alacsony árfekvésü, de fejlett RFID technológia bevezetésével az utánpótlás ellátási folyamatnál, leltári illetve termék-nyomkövetési folyamatoknál. Ebben a cikkben egy esettanulmányt írunk le a gyártás során fellépő termék-nyomkövetésre RFID technológia segítségével.

Kulcsszavak: RFID, nyomkövetési pozíció, tengerészeti hajóipar. 


\section{Introduction}

The discovery of millions barrels of petroleum, never before explored, in the presalt layer, revived the shipbuilding industry in Brazil, dormant since the 80's. The presalt is a sequence of sedimentary rocks between 5 and 7 thousand meters below the sea surface. Petrobras - Brazilian Petroleum S.A. - is a state-owned company that operates in the energy field, responsible for the discovery and the exploration of the oilfields in the pre-salt layer. With investments of R $\$ 11.2$ billion ( $€ 3.5$ bi), between 2007 and 2020, the company will renew and expand the fleet of ships, what boosted the shipbuilding industry in the country the past years. This demand for new oil tankers and oil platforms attracted several companies to build and modernize shipyards in Brazil. The Naval Cluster in the south of Brazil has three operating shipyards: Rio Grande Shipyard (ERG), Rio Grande Shipyard 2, Wilson Sons; and one being built: Brazilian's Shipyards [1].

One of the most expressive problems identified in the ERG, for example, was the warehouse management - when was necessary to locate products before and after being manufactured, in which there is few applied technology. This may generate losses of rework and additional costs of acquiring the same material for the production.

With application of tracking technology in manufacturing plants, like Radio Frequency Identification (RFID), will allow a higher level of automation in this process, allowing better monitoring of manufacturing resources and a better management of them. To identify them and allocate them correctly at each step of production, decreases the idle times of the equipment and reduces the production costs. This paper presents a case study for applications of RFID technology to track manufacturing resources in a shipyard.

\section{The RFID technology}

The automatic identification is related to methods that automatically identifies objects, collect data about them, and enter it directly into computers systems, without the intervention of a human [2]. The main objective of these systems is to increase the efficiency, reduce errors and release staff to perform higher added value work.

RFID systems works with three different entities: tags, readers and servers. The RFID tags are silicon-based microchips transponders, with a unique serial number (ID), and an antenna to receive and transmit signals. The communication between the reader and the tags is done through radio waves. There are three different types of tags: active, passive and semi-passive [3]:

- An active tag has an internal battery responsible to power the radio frequency (RF) circuit;

- A passive tag has no internal power supply and uses the energy from the reader's radio waves to power the RF circuit;

- The semi-passive tags communicate like the passive ones, but has an internal battery to power others circuits, like sensors and memory.

The active tags could communicate in distances that reaches 90 meters from the reader otherwise, in the semipassive tags the communication is more restricted and with the passive ones, reaches only few meters. Passive tags have smaller dimensions and lower costs comparing with the active ones, but their functionality is reduced as well.

After all, one or more servers store the relationship tag ID-object and receive the information from the readers to perform calculations such as position tracking or access control. 


\section{Proposal}

To move huge metal pieces, parts of the ship that is being built, is used a special truck, named KAMAG. These vehicles are able to carry 1.000 tons each one, and combined, could reach 5.000 tons. Today, three of these trucks are being used in the ERG. This project has the objective to track the position of those trucks inside the total area of the shipyard and be able to show the current position during the drive period. This way, it will allow a better management of this resource and identify idles periods.

To do that, it will be implemented a RFID network into the shipyard. It was selected the reader RX202 and the active tags IP67, both from Wavetrend company. The data received from the reader is the tag ID and the signal strength (RSS). The attenuation of the emitted signal strength is function of the distance between the receiver and the emitter. Having a tag into a grid of readers, and knowing the correct position of each reader, it is possible, by different mathematical methods, determine the position of the tag, using the RSS data received from each reader. We selected the trilateration method - it has a good precision and requires little computational effort, comparing to the others ones [4].

Usually, the tag is fixed in the object that is being tracked, but knowing that the maximum distance between the reader and the tag selected that allows the communication is 20 meters, and the total area of ERG is $550,000 \mathrm{~m}^{2}$, the total number of readers necessary to reach all the shipyard's area would be economically unviable. The cost of the reader is much higher than the tag, because of this, it was decided a different approach: to reverse the relationship readertag: put the reader in the object tracked and the tag in a fixed position. To do this, the problem was how to fix the readers in the trucks and stablish the communication with the servers - usually done by RS232 network.

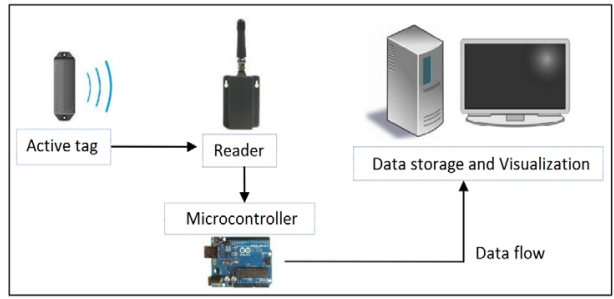

1. Figure. The system components

To establish the wireless communication between the reader and the server, it was developed a microcontroller interface, see in "FIGURE 1" the components of the system. The microcontroller chosen was the Arduino, because is a low cost open-source electronic platform. The wireless communication is made through Xbee radio module.

A generic RFID communication framework [6] was adapted to be installed in the microcontroller, allowing the communication with the reader. A local storage module was developed making the microcontroller able to store the received data locally (in a SD-card) if the communication with the server was lost. Another module enabling the communication peer-to-peer between two Xbee modules was also adapted.

The server receives the data from the Xbee interface and store all the information into a SQL database. A visual interface developed in Allegro shows to the user the position of each truck and the current time into the RFID grid. The user can generate reports with all tracked positions within a given period. This could be used to solve shorter path problems, design better trajectories and increase the activity of the trucks, decreasing the production costs.

\section{Conclusion}

This paper proposes a RFID network prototype that could track some resources applied in the shipbuilding manufacturing. 
In the future, it could help the warehouse management by simple adding a tag in the products stored. This way, the truck will localize the correct piece among others just passing by the storage area.

The first prototype built was tested in a controlled environment and approved. The access to the shipyard is restricted because it offers various accidents risks and runs 24 hours per day. For these reasons, it was not possible to test the current prototype in the field yet, what is expected to be working the end of this year.

\section{Acknowledgment}

This article was developed during the exchange program Science Without Borders, supported by the Brazilian government institutions: CAPES and the Ministry of Education.

This work was also sponsored by the Hungarian National Scientific Fund (OTKA 105846). The project was realized through the assistance of the European Union, with the co-financing of the European Social
Fund, TÁMOP-4.1.1.C-12/1/KONV-20120002.

\section{References}

[1] Santos, E. B: Rastreamento em ambientes de construção e montagem naval. Rio Grande, RS: [s.n.], Jul. 2012.

[2] Kwok, S. K., Tsang A. H. C., Ting J. S. L., Lee W. B., Cheung, B. C. F: An intelligent RFID-based electronic anti-counterfeit system (InRECS) for the manufacturing industry Proceedings of the 17th World Congress The International Federation of $\mathrm{Au}-$ tomatic Control, 2008, nt.ntnu.no

[3] Hillbrand, C., Robert, S: Shipment Localization Kit: An Automated Approach for Tracking and Tracing General Cargo, Management of Mobile Business, 2007, ieeexplore.ieee.org

[4]Bouet, M., Dos Santos, AL: RFID tags: Positioning principles and localization techniques, Wireless Days, 2008, ieeexplore.ieee.org

[5] Grandi, E. L: iTraking - Um framework para rastreamento através de RFID, Rio Grande, RS: [s.n.], Dez. 2014. 